\title{
Partitioning of macronutrients and nutritional efficiency in fertigated prata banana
}

\author{
José Aridiano Lima de Deus ${ }^{1}$, Júlio César Lima Neves ${ }^{2}$, Antonio João de Lima Neto ${ }^{3}$, \\ William Natale ${ }^{4}$, Víctor Hugo Alvarez V. ${ }^{5}$, Fabricio Martinazzo Regis de Albuquerque ${ }^{6}$
}

\begin{abstract}
Adequate nutritional management of any plant species requires quantifying the nutrients accumulated in the plant and knowing their allocation in the different organs. The objective of this study was to evaluate the partitioning, accumulation, export of macronutrients and the nutritional efficiency of fertigated Prata banana plants. A historical survey of annual fruit productivity was conducted in 66 plots of Prata banana, selecting four that met the annual productivity classes $(<$ $30.0 ; 30.0 \leq 37.5 ; 37.5 \leq 45.0$ and $>45.0 \mathrm{t} \mathrm{ha}^{-1}$ ). The dry matter weights of the different organs of parent plant and follower, as well as the respective contents of macronutrients, were used to estimate the accumulation, partitioning, export, sequence of accumulation of macronutrients and nutritional efficiency using the coefficient of biological utilization (CBU). The partitioning of macronutrient accumulation varied with productivity class and plant organ. The average distribution of nutrients in the parent plant and in the follower ranged from 67.5 to $82.8 \%$ and from 17.2 to $32.5 \%$, respectively. Macronutrient exports per ton of bunch were 4.334, 1.660, 0.361, 0.224, 0.148 and $0.119 \mathrm{~kg} \mathrm{t}^{-1}$ for $\mathrm{K}, \mathrm{N}, \mathrm{P}, \mathrm{Mg}, \mathrm{S}$ and $\mathrm{Ca}$, respectively. Banana mats have a nutrient partitioning pattern for different yields, that is, this work provides evidence that there is an "ideal compartmentalization" that promotes higher productivity; however, more research is needed to support this statement. The most exported nutrients per ton of bunch were $\mathrm{K}$ and $\mathrm{N}$. The descending order of accumulation was: $\mathrm{K}>\mathrm{N}>\mathrm{Ca}>$ $\mathrm{Mg}>\mathrm{P}>\mathrm{S}$. It was observed that the CBUs of $\mathrm{N}$ and $\mathrm{P}$ were less sensitive to productivity variations, while those of $\mathrm{Ca}$ and $\mathrm{Mg}$ were the most sensitive.
\end{abstract}

Index terms: Musa spp.; redistribution; efficiency of utilization.

\section{Partição de macronutrientes e eficiência nutricional em bananeira-prata fertirrigada}

Corresponding author: limanetoagro@hotmail.com

Received: February 212020 Accepted: June 01, 2020

Copyright: All the contents of this journal, except where otherwise noted, is licensed under a Creative Commons Attribution License.

\begin{abstract}
Resumo - O adequado manejo nutricional de qualquer espécie vegetal requer quantificar os nutrientes acumulados na planta e conhecer sua alocação nos diferentes órgãos. O trabalho teve como objetivo avaliar a partição, o conteúdo, a exportação de macronutrientes e a eficiência nutricional de plantas de bananeira Prata fertirrigadas. Realizou-se um levantamento histórico de produtividade anual de frutos em 66 talhões de bananeira Prata, selecionando-se quatro que atendessem às classes de produtividade anual $\left(<30,0 ; 30,0 \leq 37,5 ; 37,5 \leq 45,0 \mathrm{e}>45,0 \mathrm{t} \mathrm{ha}^{-1}\right)$. Utilizando-se a massa de matéria seca dos diferentes órgãos da planta-mãe e da planta-filha, bem como os respectivos teores de macronutrientes, estimou-se o conteúdo, a partição, a exportação, a sequência de acúmulo dos macronutrientes e a eficiência nutricional por meio do coeficiente de utilização biológica (CUB). A partição do conteúdo de macronutrientes variou com a classe de produtividade e o órgão da planta. A distribuição média de nutrientes na planta-mãe e na planta-filha apresentou amplitudes de 67,5 a 82,8 \% e de 17,2 a $32,5 \%$ respectivamente. As exportações de macronutrientes por tonelada de cacho foram 4,$334 ; 1,660 ; 0,361 ; 0,224 ; 0,148$ e $0,119 \mathrm{~kg} \mathrm{t}^{-1}$ para K, N, P, Mg, S e Ca respectivamente. A bananeira possui padrão de partição de nutrientes para diferentes rendimentos, ou seja, o trabalho traz evidências de que existe uma "compartimentalização ideal" que promove maiores produtividades, entretanto há necessidade de mais pesquisas para suportar essa afirmação. Os nutrientes mais exportados por tonelada de cacho foram $\mathrm{K}$ e N . A ordem decrescente de acúmulo foi: $\mathrm{K}>\mathrm{N}>\mathrm{Ca}>\mathrm{Mg}>\mathrm{P}>\mathrm{S}$. Observou-se que os CUBs de $\mathrm{N}$ e $\mathrm{P}$ foram menos sensíveis às variações de produtividade, enquanto $\mathrm{Ca}$ e $\mathrm{Mg}$ foram os mais sensíveis.
\end{abstract}

Termos para Indexação: Musa spp.; redistribuição; eficiência de utilização. 


\section{Introduction}

Banana requires large amounts of nutrients compared to other fruit crops, especially with respect to $\mathrm{K}$ and $\mathrm{N}$ and, in order to maintain its vegetative and reproductive growth satisfactorily, requires the supply of nutrients in adequate quantities and proportions throughout the cultivation cycle (RATKE et al., 2012; FRATONI et al., 2017).

Banana mats have high dry matter production and accumulate a large amount of nutrients in vegetative organs and fruits (NEVES et al., 1991; SOARES et al., 2008; HOFFMANN et al., 2010). Such high nutritional requirement is partly supplied by soil, fertilizer application and cycling of nutrients present in the plant residues produced during cultivation, which can be mineralized and subsequently absorbed by plants (TEIXEIRA et al., 2008; MOREIRA; FAGERIA, 2009a; BRITO et al., 2017).

The quantification of nutrients accumulated in the various organs of the plant, as well as the percentage exported with the harvest of bunches, is essential for designing fertilizer recommendation programs and for the adequate nutritional management of this fruit crop (SOARES et al., 2008; SILVA et al., 2015). Due to the large amounts of phytomass produced by banana mats and of nutrients contained, which return to the soil through crop residues, part of the nutritional requirement of the crop is supplied by the nutrients recovered in the soilplant system after harvesting the bunches, reducing the amount of fertilizers to be supplied to plants (SOARES et al., 2008; SILVA et al., 2015).
Several studies evaluating the production of dry matter and accumulation of nutrients by banana plants have been conducted under rainfed conditions, usually obtaining low yields (HOFFMANN et al., 2010). Thus, using these data limits the estimation of the nutritional requirement of banana mats in fertilization programs in irrigated areas aimed at obtaining high productivity.

Therefore, in order to improve fertilization programs that use data based on nutritional requirement, relating them to different productivity classes, this study aimed to estimate and evaluate the partitioning, accumulation and export of nutrients, besides the nutritional efficiency of Prata banana fertigated in the state of Ceará, Brazil.

\section{Material and methods}

\section{Area description}

The experiment was conducted in the first half of 2014 at the company Sítio Barreiras Fruticultura LTDA., located in the municipality of Missão Velha, Ceará, Brazil $\left(7^{\circ} 35^{\prime} 90^{\prime \prime} \mathrm{S}\right.$ and $\left.39^{\circ} 21^{\prime} 17^{\prime \prime} \mathrm{W}\right)$, with an altitude of approximately $442 \mathrm{~m}$. The climate of the region, according to the Köppen-Geiger classification, is Aw - tropical with dry season in the winter and rains concentrated in the summer.

The company has 66 plots (with an average area of 3.26 ha each) of fertigated Prata banana. The soil in these plots is a Neossolo Quartzarênico (Entisol), classified according to the Brazilian Soil Classification System - SiBCS (EMBRAPA, 2013), and its chemical characteristics are presented in Table 1.

Table 1. Productivity classes and chemical characteristics of soils $(0-20 \mathrm{~cm})$ of the plots cultivated with fertigated Prata banana

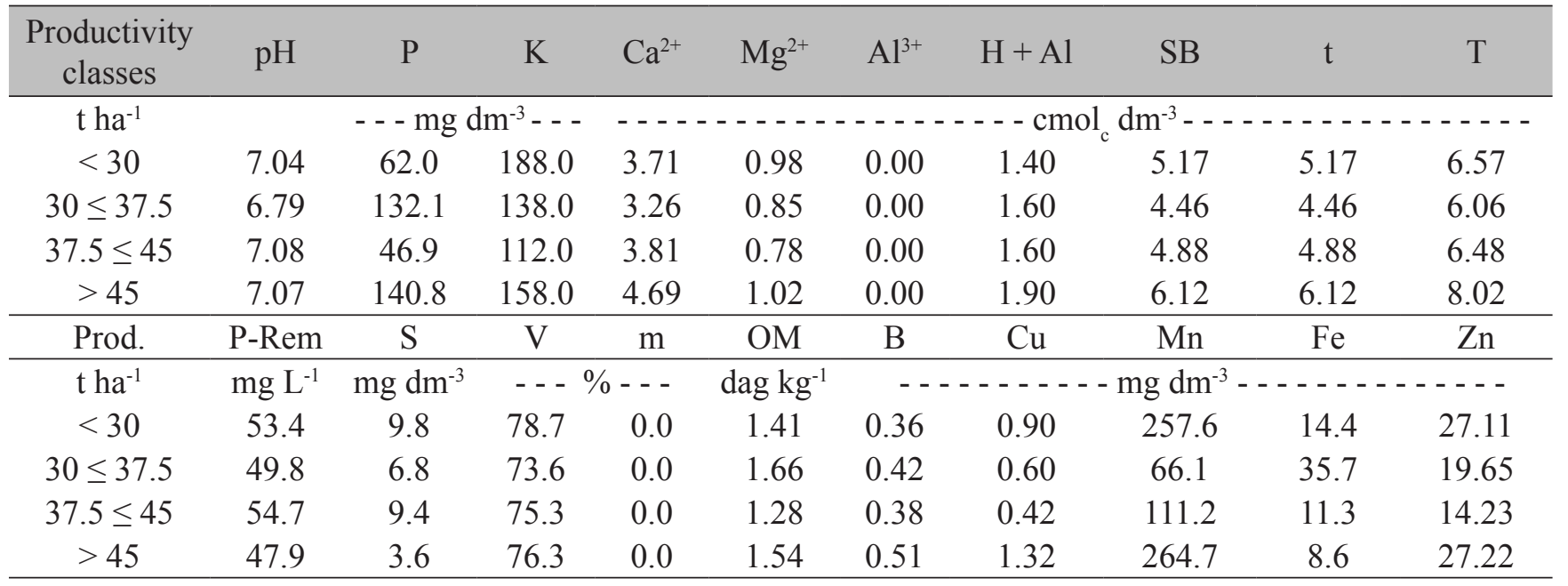

$\mathrm{pH}$ in water at ratio of 1:2.5; $\mathrm{P}, \mathrm{K}, \mathrm{Cu}, \mathrm{Mn}, \mathrm{Fe}$ and $\mathrm{Zn}-$ Mehlich-1 extractant; $\mathrm{Ca}^{2+}, \mathrm{Mg}^{2+}$ and $\mathrm{Al}^{3+}-1 \mathrm{~mol} / \mathrm{L} \mathrm{KCl} \mathrm{extractant} ; \mathrm{H}+\mathrm{Al}-0.5 \mathrm{~mol} / \mathrm{L}$ calcium acetate extractant at $\mathrm{pH} 7.0 ; \mathrm{SB}=$ sum of exchangeable bases; $\mathrm{t}=$ effective cation exchange capacity; $\mathrm{T}=$ cation exchange capacity at pH 7.0; P-rem = remaining phosphorous; $\mathrm{S}$ - monocalcium phosphate extractant in acetic acid; $\mathrm{V}=$ base saturation index; $\mathrm{m}=\mathrm{Aluminum}$ saturation index; $\mathrm{OM}=$ Organic matter obtained from organic carbon $\times 1.724$ (Walkley-Black); B - hot water extractant. 
Initially, a survey of annual fruit productivity was carried out in the various plots of the company, comprising the period between 2010 and 2013 . Four productivity classes $\left(<30.0 ; 30.0 \leq 37.5 ; 37.5 \leq 45.0\right.$ and $>45.0$ t ha $\left.^{-1}\right)$ were established and, subsequently, four plots that met these productivity classes were selected from the 66 plots of the company.

\section{Sample collection and preparation}

Four banana mats, composed of parent plant and follower, were randomly sampled in each plot during the period in which the parent plant bunch was at the point of harvest, totaling 16 banana mats or sampling units. Each banana mat was partitioned into a parent plant (rhizome, pseudostem, leaves, stalk and fruit) and follower (rhizome, pseudostem and leaves) to obtain dry matter weight $(\mathrm{DMw})$ of all plant organs.

Plant tissue samples were dried in a forced air circulation oven at temperature of $65{ }^{\circ} \mathrm{C}$ for $72 \mathrm{~h}$ and then ground in Wiley-type mill using a $0.85-\mathrm{mm}$-mesh sieve $(20 \mathrm{mesh})$. Subsequently, the total contents of macronutrient were determined in the samples, according to the methodology described by Silva (2009).

Accumulation, partitioning and export of nutrients in banana

In order to obtain the accumulation of macronutrients $\left(\mathrm{kg} \mathrm{ha}^{-1}\right)$ in banana, the dry matter weights of the different organs of the parent plant and follower were multiplied by the respective nutrient contents, considering a stand of 1,275 banana mats per hectare. Subsequently, the partitioning of macronutrients for the different organs of the parent plant and follower, the export of macronutrients by the parent plant (\%) and the amount of macronutrients exported per ton of bunch $\left(\mathrm{kg} \mathrm{t}^{-1}\right)$ were determined.

In addition, the order of macronutrient accumulation was also established in the dry matter weights of banana mat (DMw_mat), parent plant (DMw_parent) and follower (DMw_follower), as well as in the different organs. All these variables were obtained according to the fruit productivity classes $(<30.0 ; 30.0 \leq 37.5 ; 37.5 \leq 45.0$ and $>45.0$ tha $^{-1}$ ).

\section{Nutritional efficiency of banana for macronutrients}

The data of dry matter weight and macronutrient accumulation in the different organs of the plant were used to calculate the coefficient of biological utilization of the nutrients (CBU_Nu $_{\mathrm{i}}$ for each organ (Equation 1), according to Barros et al. (1986) and Oliveira et al. (2005).

$$
\text { CBU_Nu } \mathrm{Nu}_{\mathrm{i}}=\frac{\text { Dry matter weight }}{\text { Accumulation of nutrient (i) }}
$$

where: CBU_Nu $\mathrm{Nu}_{\mathrm{i}}$ is expressed in $\mathrm{kg} \mathrm{kg}^{-1}$, and dry matter weight and nutrient accumulation are expressed in $\mathrm{kg} \mathrm{ha}^{-1}$.

\section{Statistical analysis}

The data were subjected to analysis of variance and the means were discriminated by the Scott-Knott test at $5 \%$ probability level (SCOTT; KNOTT, 1974).

\section{Results and discussion}

\section{Partitioning and export of macronutrients}

The partitioning of macronutrient accumulation in banana varied with the productivity classes, with the organs of the plant and within the banana mat itself (Figure 1). For $\mathrm{N}$, the largest accumulation were observed in the parent plant in all productivity classes and, in general, the order of accumulation in the organs was: pseudostem $>$ fruit $>$ leaf $>$ rhizome $>$ stalk (Figure 1A). However, this order varied according to the productivity class, and it was observed that the $\mathrm{N}$ accumulation in the leaves was higher than that in the fruit in the plots of lower productivity $(<$ $30 \mathrm{tha}^{-1}$ ) and there was higher accumulation in the fruit than in the other organs, in the most productive plots $(>$ $\left.45 \mathrm{tha}^{-1}\right)$. 


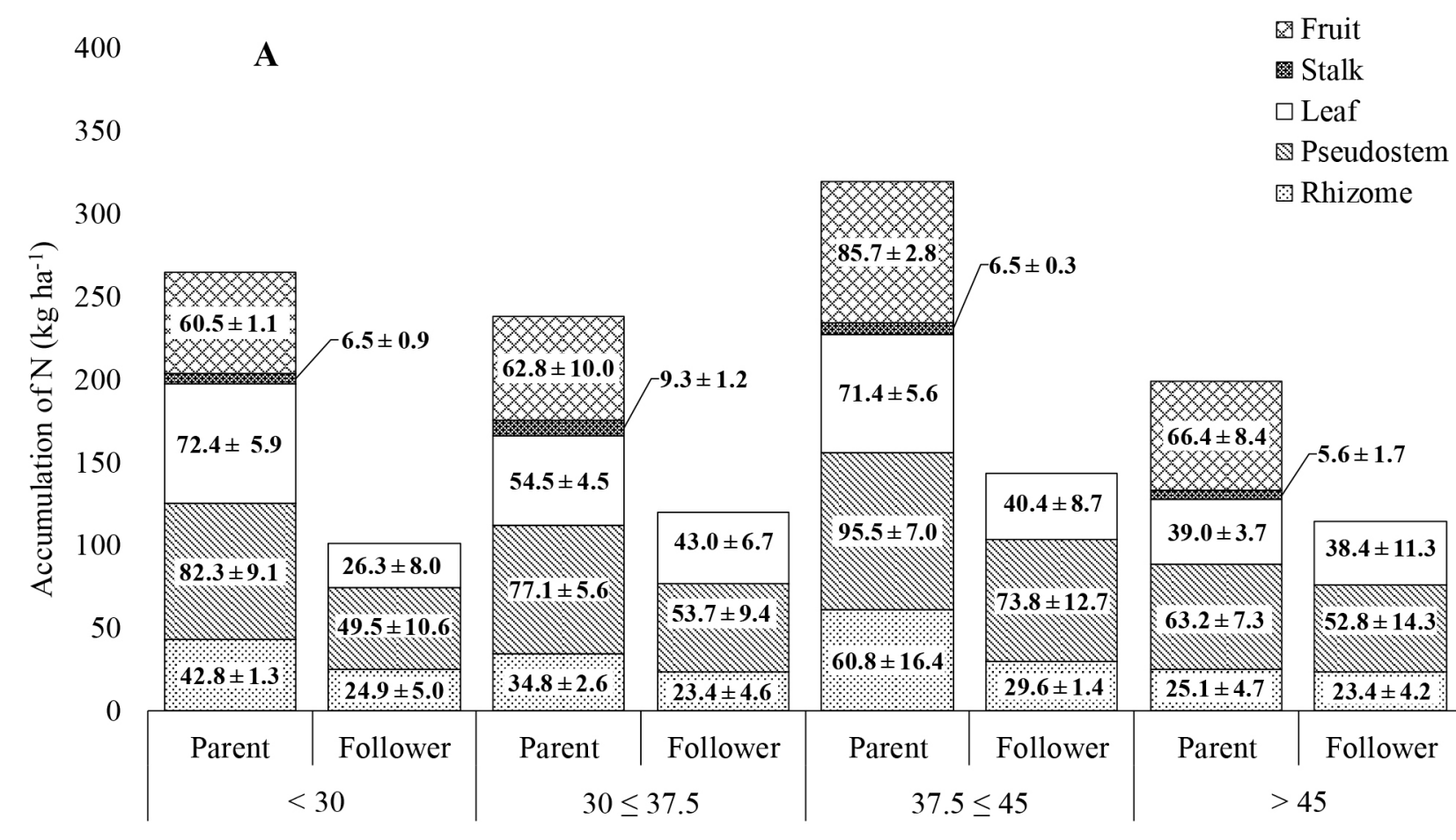

Productivity classes $\left(\mathrm{t} \mathrm{ha}^{-1}\right)$

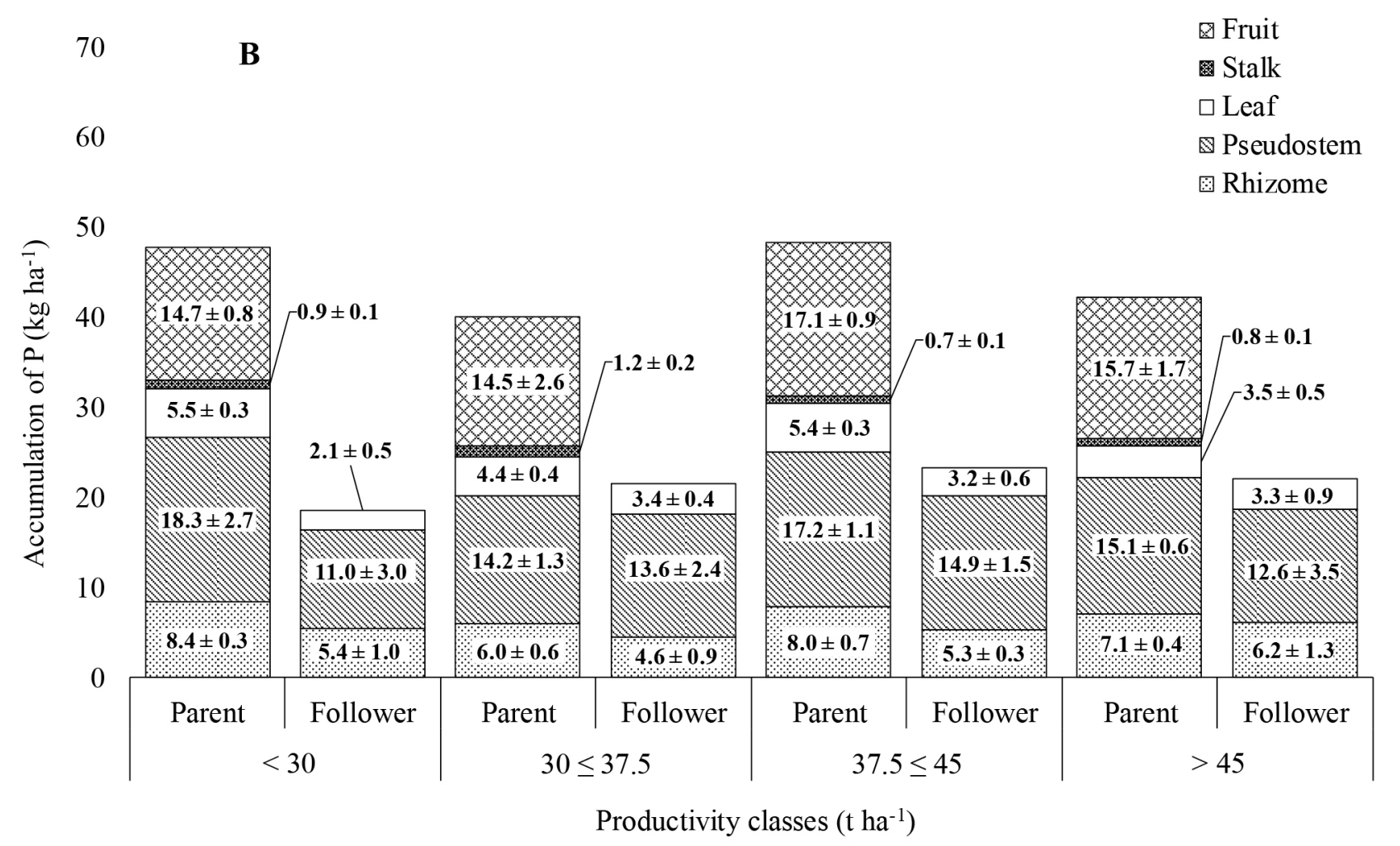

Continue.. 


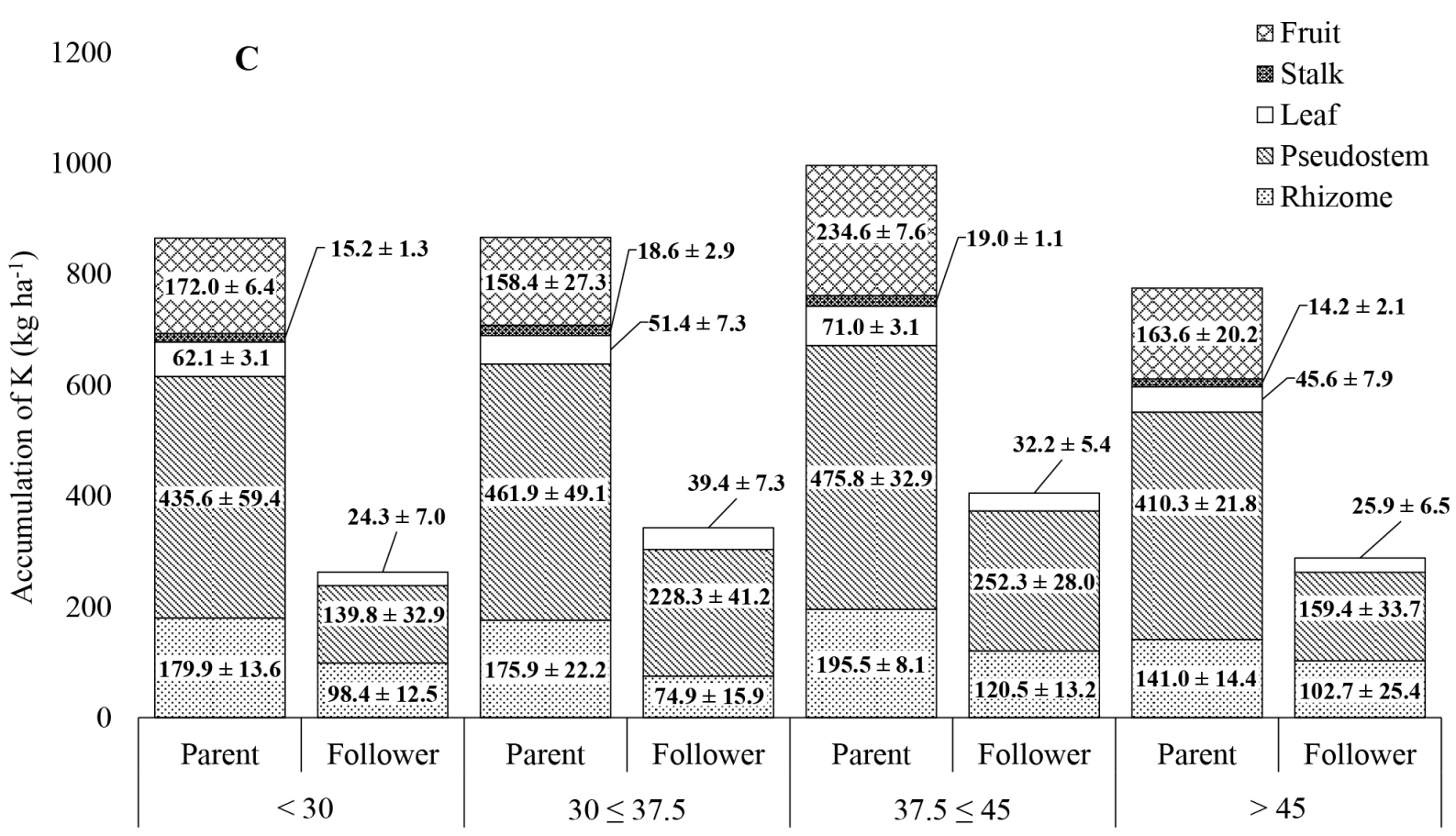

Productivity classes $\left(\mathrm{t} \mathrm{ha}^{-1}\right)$

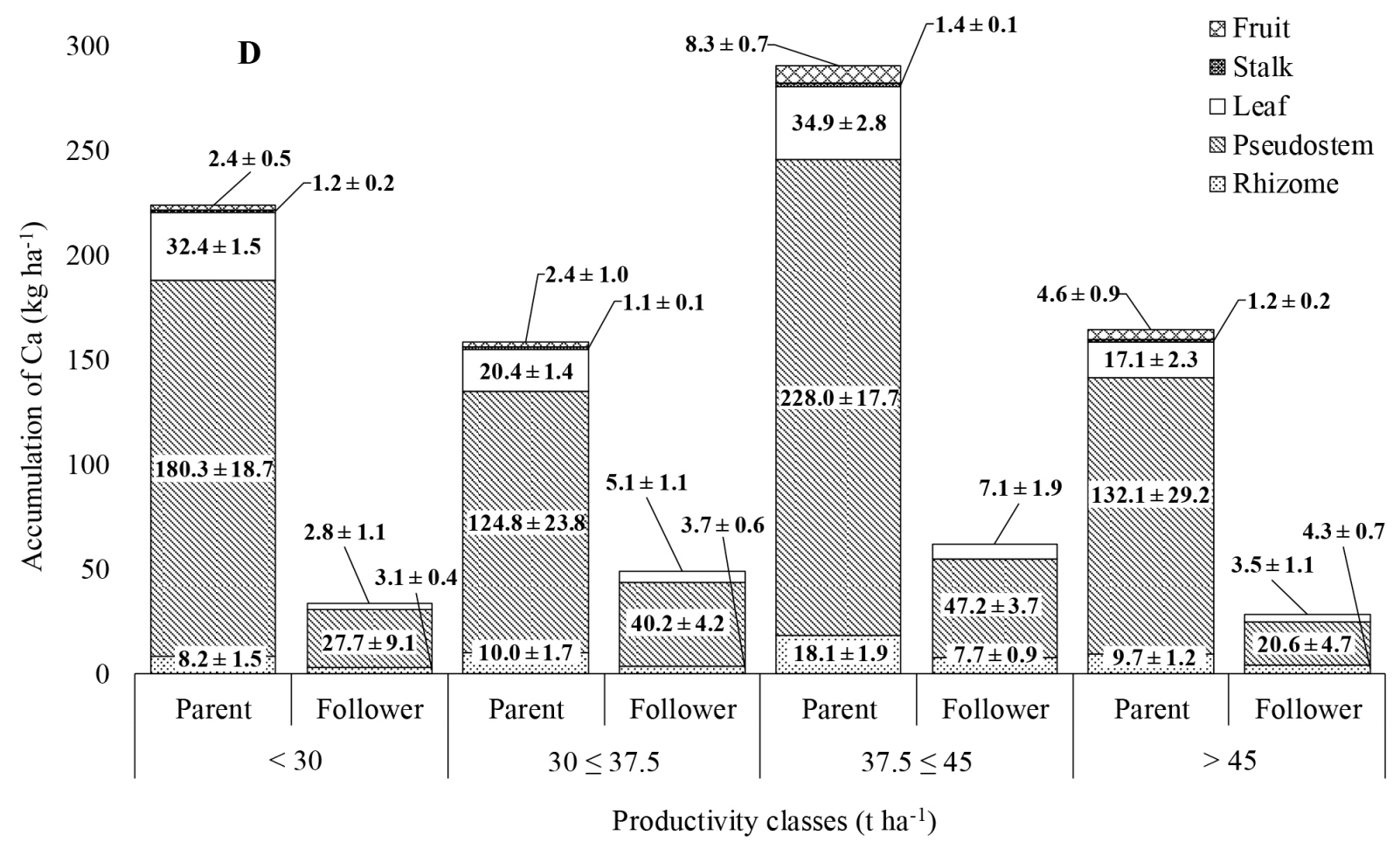

Continue... 


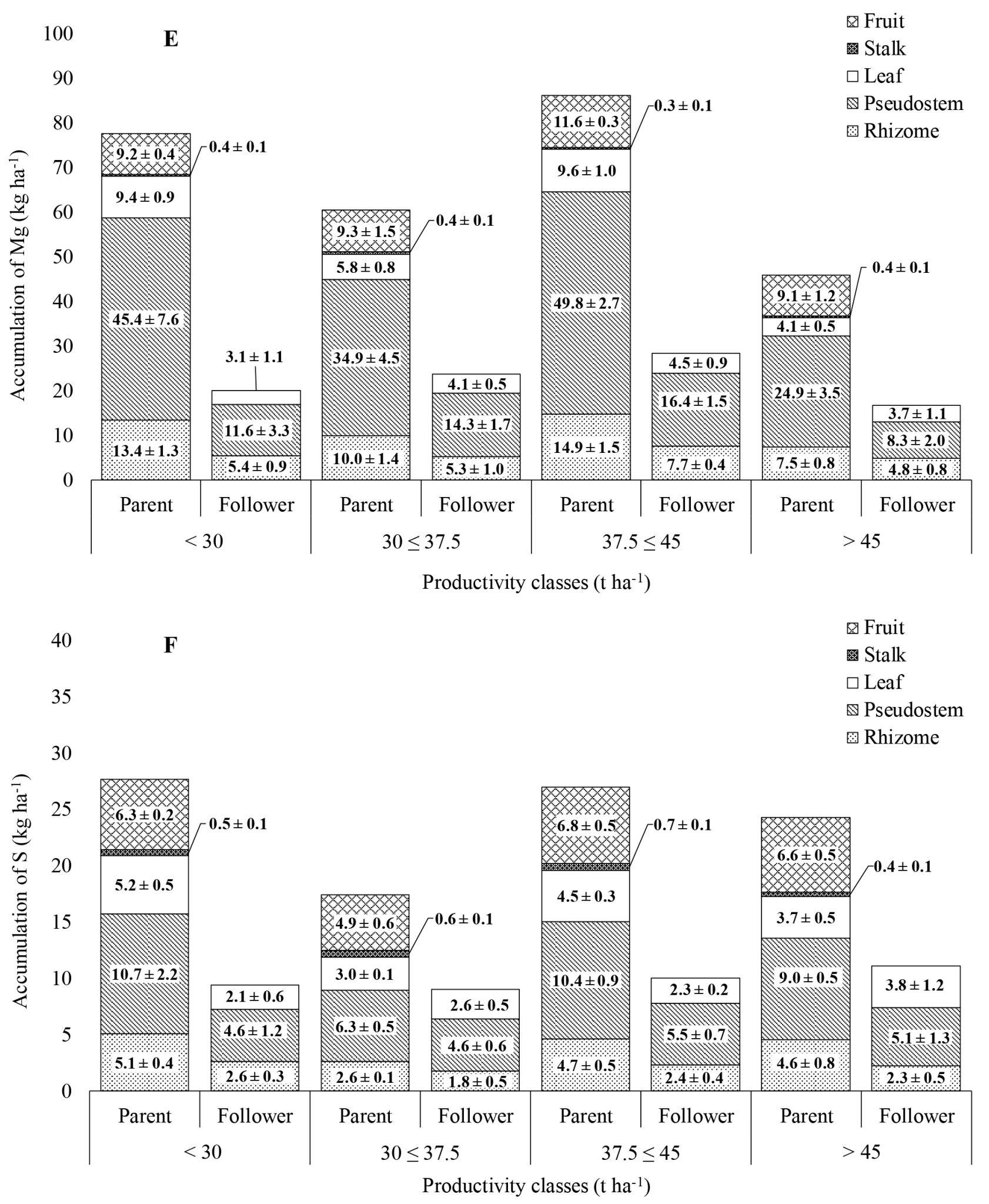

Figure 1. Average values and standard error of the partitioning of nitrogen (A), phosphorus (B), potassium (C), calcium (D), magnesium (E) and sulfur (F) accumulation in different organs of fertigated banana for different productivity classes 
Of the total $\mathrm{N}$ accumulated in the banana tree, the fruits of plants from the plots with productivity lower than $30 \mathrm{t} \mathrm{ha}^{-1}$ accumulated on average $22.9 \%$ of this nutrient. This accumulation was proportional to the increase in productivity and reached $33.3 \%$ in the fruits of plants that produced above $45 \mathrm{t} \mathrm{ha}^{-1}$ (Figure 1A). However, the $\mathrm{N}$ accumulation in the leaves was inversely proportional to the increase in productivity and decreased from 27.4 to $19.6 \%$ between plants that produced less than 30 and more than $45 \mathrm{t} \mathrm{ha}^{-1}$, respectively. These results indicate that under high productivity the $\mathrm{N}$ allocated in the leaves was redistributed to the fruits due to its high mobility in the phloem (MARSCHNER, 2012).

In general, the main carbohydrates formed in photosynthesis are starch (reserve) and sucrose (transport), the latter being synthesized in the cytosol of cells and redistributed via phloem. Plants under $\mathrm{N}$ deficiency have reduction of growth and changes in dry matter partitioning, with decreases in the concentration of total soluble sugars and non-reducing sugars, increasing the concentration of leaf starch (CRUZ et al., 2004). This favors greater accumulation of $\mathrm{N}$ in the leaf, to the detriment of the fruit in plantations with lower productivity. On the other hand, high $\mathrm{N}$ doses reduce fruit productivity and increase the thickness of banana leaf mesophyll (MELO et al., 2010), i.e., plants with low productivity allocate more $\mathrm{N}$ in the leaf instead of in the fruit, regardless of the conditions of low or high availability of this nutrient. It is worth pointing out that in this case the leaf was an important organ for $\mathrm{N}$ accumulation.

The order of $\mathrm{P}$ accumulation, as observed for $\mathrm{N}$, also varied with the productivity class (Figure 1B). In the parent plants of plots with productivity lower than $30 \mathrm{t} \mathrm{ha}^{-1}$, the decreasing pattern of nutrient accumulation in the organs was: pseudostem $>$ fruit $>$ rhizome $>$ leaves $>$ stalk. In plants with productivity greater than $45 \mathrm{t} \mathrm{ha}^{-1}$, the accumulation of $\mathrm{P}$ becomes higher in the fruits, to the detriment of pseudostem. Considering only the fruits, their accumulations of $\mathrm{P}$ were on average $30.7 \%$ in the least productive plants $\left(<30 \mathrm{t} \mathrm{ha}^{-1}\right)$ and $37.1 \%$ in the most productive plants $\left(>45 \mathrm{t} \mathrm{ha}^{-1}\right)$. Thus, it is observed that Prata banana has a partitioning pattern that varies with productivity, that is, under higher productivity the plant will allocate most nutrients in the fruits. $P$ is related to the storage and transport of energy in the form of ATP, being an energy source in metabolic processes of the plant, besides being part of DNA and RNA molecules, responsible for genetic information and synthesis of plant proteins (MARSCHNER, 2012).

$\mathrm{K}$ was the most accumulated nutrient in Prata banana plants, with average value of $875.4 \mathrm{~kg} \mathrm{ha}^{-1}$ (Figure 1C). Its order of accumulation in the various organs differed from those observed for $\mathrm{N}$ and $\mathrm{P}$, being generally higher in pseudostem, followed by fruit, rhizome, leaf and stalk (Figure 1C). This order varied with the productivity class, and it was observed that in the least productive plants ( $<$ $30 \mathrm{tha}^{-1}$ ) the rhizome accumulated more $\mathrm{K}$ than the fruits, with the opposite occurring in the most productive plants $\left(>45 \mathrm{tha}^{-1}\right)$, in which $\mathrm{K}$ accumulation was higher in fruits than in the rhizome. This may have occurred because the banana tree has a high and continuous absorption of $\mathrm{K}$ until harvest (SOARES et al., 2008). In addition, this nutrient has high mobility in the phloem of the crop (MOREIRA; FAGERIA 2009b), which may have contributed for K to be redistributed from other organs to the fruits under the highest productivities. This nutrient plays an important role in respiration, chlorophyll formation, photosynthesis and water regulation (EPSTEIN; BLOOM, 2006; AULAR; NATALE, 2013; FRATONI et al., 2017), especially as an activator of many enzymes (MARSCHNER, 2012).

Unlike the partitioning of $\mathrm{N}$ and $\mathrm{P}$ in the banana plant, the allocation of $\mathrm{K}$ in fruit and rhizome as a function of productivity does not seem to be related to the competition between the sink organs, but rather to its direct action on the synthesis, transport and accumulation of sugars in the fruit. $\mathrm{K}$ is important in photosynthesis, acting in stomatal opening, $\mathrm{CO}_{2}$ entry and, later, in the transport via phloem of carbohydrates produced in photosynthesis to the sink organs of the plant, especially the fruit (EPSTEIN; BLOOM, 2006; MARSCHNER, 2012; AULAR; NATALE, 2013).

Despite being the third most accumulated nutrient in the plants, Ca had the lowest accumulation in the fruit, corresponding to only 1.1 and $2.8 \%$ of the total in the least and most productive plants, respectively (Figure 1D). In contrast, the pseudostem was the organ with largest $\mathrm{Ca}$ accumulation in the plant, followed by leaf, rhizome, fruit and stalk. Silva et al. (2015) also found higher $\mathrm{Ca}$ accumulation in the leaves and pseudostem of banana mats, cv. D'Angola, and attributed this result to the active participation of these organs in the assimilation of photosynthates, as well as to the fact that $\mathrm{Ca}$ stimulates the development of leaves and roots. On the other hand, this lower $\mathrm{Ca}$ accumulation in the fruits is due to its low mobility in the phloem, that is, $\mathrm{Ca}$ redistribution from the leaf to the fruits is, in general, physiologically insignificant (MARSCHNER, 2012). Its transport in the plant occurs in only one direction, from the roots to the shoots, through the transpiration flow (via xylem), being preferably transported to parts of higher transpiration (MALAVOLTA, 2006; AULAR; NATALE, 2013).

$\mathrm{Mg}$ showed the same behavior of $\mathrm{K}$ regarding its accumulation in the plant and its pattern of accumulation in the rhizome and fruit (Figure 1E). Its accumulation in fruits, in relation to the total accumulated in the plant, was directly proportional to the increase in productivity, from 11.8 to $19.8 \%$ between the lowest and highest levels of productivity. However, considering the accumulation in the leaves, it can be observed that there was a reduction from 12.0 to $8.9 \%$, indicating that under high productivity 
$\mathrm{Mg}$ tends to be remobilized from leaves to fruits. This similarity between $\mathrm{Mg}$ and $\mathrm{K}$ may be related to the high mobility of these nutrients in the phloem of the plant (MOREIRA; FAGERIA, 2009b).

For S, the descending order of accumulation was: pseudostem, fruit, rhizome, leaf and stalk (Figure 1F). Since the fruit is the part exported by the harvest, on average, they accumulated $25.8 \%$ of the total $\mathrm{S}$ present in the plant. This nutrient is present in amino acids and acts in protein synthesis, affecting photosynthesis, respiration and N fixation (EPSTEIN; BLOOM, 2006). The pattern of S partitioning was the same observed for $\mathrm{N}$ and can be explained by the fact that $\mathrm{S}$ participates in $\mathrm{N}$ metabolism (MARSCHNER, 2012).

After flowering, the bunch becomes the main sink in the banana plant (SOARES et al., 2005), and mobile nutrients are remobilized in the phloem from the leaf to the fruit (MOREIRA; FAGERIA, 2009a). However, it was observed in this study that the increase in N, P, K and $\mathrm{Mg}$ accumulation in the fruit, to the detriment of other organs, occurred according to the productivity classes (Figure 1). It is evident that different nutrient allocation relationships promote variation in productivity, that is, there is an "ideal compartmentalization" that is related to higher productivities. This may be indicative that the simple absorption, even in sufficient quantities, may not translate into productivity gains by Prata banana, if this compartmentalization does not occur.
The nutrients N, P, K and Mg, which showed this differentiated behavior in the patterns of accumulation in the various organs, are mobile in the phloem (MARSCHNER, 2012), that is, they are easily redistributed from an organ (source), such as the leaf, to other organs (sink), mainly the fruit, as observed in banana by Moreira and Fageria (2009b). This biochemical cycling of nutrients by the plant is very beneficial in situations where the supply of nutrients via soil is deficient or temporarily interrupted, for example because of water deficit in the soil (MARSCHNER, 2012).

In the follower, pseudostem was the organ with highest accumulations of all macronutrients (Figure 1). For $\mathrm{N}$ and $\mathrm{S}$, on average, the accumulation was higher in the pseudostem, followed by leaves and rhizome. For P, K, $\mathrm{Ca}$ and $\mathrm{Mg}$, the accumulation sequence was: pseudostem $>$ rhizome $>$ leaf.

The partitioning of the total accumulation of nutrients in the banana mat (parent plant and follower) is presented in Table 2. Among the macronutrients, the sequence of allocation in the parent plant, in percentage, was: $\mathrm{Ca}>\mathrm{Mg}>\mathrm{K}>\mathrm{S}>\mathrm{N}>\mathrm{P}$. In general, the range of allocation of macronutrients varied from 65.6 to $82.8 \%$ in the parent plant and from 17.2 to $34.4 \%$ in the follower, values that demonstrate that the follower is an important sink of nutrients in the banana mat during the harvest period. These results indicate the importance of nutrient replacement in order to meet the requirements for essential elements not only of the parent plant, but also of the banana mat, as concluded by Soares et al. (2008).

Table 2. Percentage of nutrient accumulation in the parent plant and in the follower of Prata banana, in plots with history of different productivity classes

\begin{tabular}{|c|c|c|c|c|c|c|c|c|c|c|}
\hline \multirow{3}{*}{ Nutrient } & \multicolumn{8}{|c|}{ Productivity classes } & \multirow{2}{*}{\multicolumn{2}{|c|}{ Average }} \\
\hline & \multicolumn{2}{|c|}{$<30$} & \multicolumn{2}{|c|}{$30 \leq 37.5$} & \multicolumn{2}{|c|}{$37.5 \leq 45$} & \multicolumn{2}{|c|}{$>45 \mathrm{tha}^{-1}$} & & \\
\hline & Parent & Follower & Parent & Follower & Parent & Follower & Parent & Follower & Parent & Follower \\
\hline & & - - - - & $\ldots$ & $-\ldots$ & $-\ldots$ & 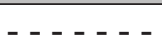 & $-\ldots$ & $-\ldots-\ldots$ & $-\ldots$ & - - $_{-1}$ \\
\hline $\mathrm{N}$ & 72.4 & 27.6 & 66.5 & 33.5 & 69.0 & 31.0 & 63.5 & 36.5 & 67.8 & 32.2 \\
\hline $\mathrm{P}$ & 72.1 & 27.9 & 65.0 & 35.0 & 67.4 & 32.6 & 65.7 & 34.3 & 67.5 & 32.5 \\
\hline K & 76.7 & 23.3 & 71.7 & 28.3 & 71.1 & 28.9 & 72.9 & 27.1 & 73.1 & 26.9 \\
\hline $\mathrm{Ca}$ & 87.0 & 13.0 & 76.4 & 23.6 & 82.4 & 17.6 & 85.3 & 14.7 & 82.8 & 17.2 \\
\hline $\mathrm{Mg}$ & 79.5 & 20.5 & 71.9 & 28.1 & 75.1 & 24.9 & 73.2 & 26.8 & 74.9 & 25.1 \\
\hline $\mathrm{S}$ & 74.7 & 25.3 & 65.9 & 34.1 & 72.8 & 27.2 & 68.5 & 31.5 & 70.5 & 29.5 \\
\hline
\end{tabular}

Some fertilizer recommendations for banana consider the importance of quantifying the export of nutrients by the bunch (stalk + fruit), as presented in Table 3. For the macronutrients N, Ca and Mg, the exports differed as a function of productivity, with higher exports for productivity above $45 \mathrm{t} \mathrm{ha}^{-1}$ (Table 3 ). In general, it was observed that $\mathrm{P}, \mathrm{N}$ and $\mathrm{S}$ were the most exported macronutrients by the parent plant at harvest, with average values of $36.9,30.1$ and $28.2 \%$, respectively, while $\mathrm{Ca}$ and $\mathrm{Mg}$ were the least exported nutrients, with 2.7 and $15.7 \%$, respectively (Table 3 ). $\mathrm{K}$ was the fourth most exported macronutrient by the parent plant, in percentage; however, in absolute values, it was the most exported and, therefore, deserves special attention and should be applied in larger quantities through fertilizers. Hoffmann et al. (2010), when evaluating the export of nutrients by six banana cultivars, three of them belonging to the same genomic group of Prata banana (AAB), obtained this same export sequence for all cultivars, except in the case of $\mathrm{Mg}$, which was the least exported in two of the cultivars studied. 
Table 3. Export ${ }^{1}$ of macronutrients by Prata banana in plots with history of different productivity classes

\begin{tabular}{lccccc}
\hline \multirow{2}{*}{ Nutrient } & \multicolumn{4}{c}{ Productivity classes } & \multirow{2}{*}{ Average } \\
\cline { 2 - 5 } & $<30$ & $30 \leq 37.5$ & $37.5 \leq 45$ & $>45 \mathrm{tha}^{-1}$ & \\
\hline $\mathrm{N}$ & $25.3 \mathrm{~b}$ & $30.2 \mathrm{~b}$ & $28.8 \mathrm{~b}$ & $36.1 \mathrm{a}$ & 30.1 \\
$\mathrm{P}$ & $32.7 \mathrm{a}$ & $38.9 \mathrm{a}$ & $36.8 \mathrm{a}$ & $39.1 \mathrm{a}$ & 36.9 \\
$\mathrm{~K}$ & $21.6 \mathrm{a}$ & $20.4 \mathrm{a}$ & $25.5 \mathrm{a}$ & $23.0 \mathrm{a}$ & 22.6 \\
$\mathrm{Ca}$ & $1.6 \mathrm{~b}$ & $2.2 \mathrm{~b}$ & $3.4 \mathrm{a}$ & $3.5 \mathrm{a}$ & 2.7 \\
$\mathrm{Mg}$ & $12.3 \mathrm{~b}$ & $16.1 \mathrm{~b}$ & $13.9 \mathrm{~b}$ & $20.6 \mathrm{a}$ & 15.7 \\
$\mathrm{~S}$ & $24.5 \mathrm{a}$ & $31.6 \mathrm{a}$ & $27.6 \mathrm{a}$ & $28.9 \mathrm{a}$ & 28.2 \\
\hline
\end{tabular}

${ }^{1}$ The export was considered the sum of the nutrient accumulated in the stalk and the fruit, in relation to the parent plant accumulation. Value referring to the average of four parent plants for each productivity class. Averages followed by the same letter in the row do not differ statistically from each other, by the Scott-Knott test, at $5 \%$ probability level.

For these nutrients, especially $\mathrm{Ca}$, which is considered immobile in the phloem (MARSCHNER, 2012), the importance is related to biogeochemical cycling, which returns them to the soil through the banana crop residues deposited after the bunches are harvested. In the case of $\mathrm{Mg}$, which is mobile in the phloem, besides this return through plant residues, there may be remobilization from the pseudostem of the parent plant (usually maintained after removal of the bunch) to the follower, through the interconnection between their rhizomes. Cavalcante et al. (2005) evaluated the translocation of $\mathrm{P}$, which is a mobile nutrient in the phloem, as well as $\mathrm{Mg}$, until six months after follower emergence, and observed uninterrupted translocation of $\mathrm{P}$ between parent plant and follower.
The return of $\mathrm{K}, \mathrm{Ca}$ and $\mathrm{Mg}$ to the soil through crop residues, on overage, is $77.4,97.3$ and $84.3 \%$, respectively. This has a practical implication in reducing the doses of fertilizers to be applied, as well as reducing production costs. In fertilization programs, it is important to consider the amount of nutrients immobilized in the banana dry matter that returns to the soil after harvest (OLIVEIRA et al., 2005; SILVA et al., 2015; BRITO et al., 2017). Hoffmann et al. (2010), evaluating the accumulation of nutrients in six banana cultivars, found that the return of nutrients to the soil, such as $\mathrm{Ca}$ and $\mathrm{Mg}$, may reach 95 and $89 \%$, respectively.

When the export of macronutrients per ton of bunch was considered, as a function of the productivity classes, there were significant differences for $\mathrm{N}, \mathrm{Ca}, \mathrm{Mg}$ and $\mathrm{S}$ (Table 4). This result strengthens the evidence that banana has a partitioning pattern, or an "ideal compartmentalization" that promotes higher productivity, considering that $\mathrm{N}$ was not the most exported nutrient for productivity above $45 \mathrm{t} \mathrm{ha}^{-1}$ compared to the other classes.

Table 4. Average values ${ }^{1}$ of the amounts of nutrients exported per ton of bunch ${ }^{2}$ in Prata banana for plots with history of different productivity classes

\begin{tabular}{llcccc}
\hline \multirow{2}{*}{ Nutrient } & \multicolumn{4}{c}{ Productivity classes } & \multirow{2}{*}{ Average } \\
\cline { 2 - 4 } & $<30$ & $30 \leq 37.5$ & $37.5 \leq 45$ & $>45 \mathrm{tha}^{-1}$ & 1.660 \\
$\mathrm{~N}$ & $-\cdots-1.525 \mathrm{~b}$ & $1.807 \mathrm{a}$ & $1.708 \mathrm{a}$ & $1.600 \mathrm{~b}$ & 0.361 \\
$\mathrm{P}$ & $0.356 \mathrm{a}$ & $0.387 \mathrm{a}$ & $0.330 \mathrm{a}$ & $0.371 \mathrm{a}$ & 4.334 \\
$\mathrm{~K}$ & $4.258 \mathrm{a}$ & $4.414 \mathrm{a}$ & $4.699 \mathrm{a}$ & $3.966 \mathrm{a}$ & 0.119 \\
$\mathrm{Ca}$ & $0.080 \mathrm{~b}$ & $0.082 \mathrm{~b}$ & $0.182 \mathrm{a}$ & $0.133 \mathrm{a}$ & 0.224 \\
$\mathrm{Mg}$ & $0.218 \mathrm{a}$ & $0.245 \mathrm{~b}$ & $0.221 \mathrm{a}$ & $0.211 \mathrm{a}$ & 0.148 \\
$\mathrm{~S}$ & $0.155 \mathrm{a}$ & $0.140 \mathrm{~b}$ & $0.138 \mathrm{~b}$ & $0.159 \mathrm{a}$ & \\
\hline
\end{tabular}

${ }^{1}$ Value referring to the average of four parent plants for each productivity class. ${ }^{2}$ The bunch in the present study refers to the stalk and fruit of the parent plant. Averages followed by the same letter in the row do not differ statistically from each other, by the Scott-Knott test, at $5 \%$ probability level. 
As previously mentioned, $\mathrm{K}$ was the fourth most exported macronutrient, when expressed as percentage, but the most exported in absolute values. On average, the decreasing order of export of macronutrients by the bunch was $\mathrm{K}>\mathrm{N}>\mathrm{P}>\mathrm{Mg}>\mathrm{S}>\mathrm{Ca}$, with exports of $4.334,1.660,0.361,0.224,0.148$ and $0.119 \mathrm{~kg} \mathrm{t}^{-1}$ bunch, respectively (Table 4). Teixeira et al. (2008) obtained the sequence $\mathrm{K}>\mathrm{N}>\mathrm{Mg}>\mathrm{P}>\mathrm{Ca}>\mathrm{S}$, with average exports of $4.50,1.75,0.24,0.20,0.14$ and $0.09 \mathrm{~kg} \mathrm{t}^{-1}$, respectively, in two cultivars belonging to the genomic group AAA and subgroup Cavendish. Hoffmann et al. (2010) found in six banana cultivars that the three most exported nutrients were $\mathrm{K}, \mathrm{N}$ and $\mathrm{S}$, while the others were variable with the cultivar. On average, exports were equal to $4.537,1.373$, $0.387,0.214,0.208,0.192 \mathrm{~kg} \mathrm{t}^{-1}$ for $\mathrm{K}, \mathrm{N}, \mathrm{S}, \mathrm{Mg}, \mathrm{P}$ and $\mathrm{Ca}$, respectively.

By comparing the results obtained in this study with those reported by Teixeira et al. (2008) and Hoffmann et al. (2010), it can be observed that $\mathrm{K}$ and $\mathrm{N}$ were the most exported nutrients per ton of bunch, with small variations for the other macronutrients, and that the quantities exported are very similar, even in the case of different genomic groups. Expressing the export of nutrients per ton of bunches tends to reduce variations of accumulation, attributed to different cultivation conditions (MALBURG; LICHTEMBERG, 1986). Therefore, it is an interesting alternative when the goal is to compare accumulation and export of nutrients in banana mats under different conditions of management, soil, plant and climate.

The accumulation of macronutrients by banana plants, in general, followed the order $\mathrm{K}>\mathrm{N}>\mathrm{Ca}>\mathrm{Mg}>$ $\mathrm{P}>\mathrm{S}$, both in the parent plant and in the follower, as well as in the banana mat, except for the productivity class $>$ $45 \mathrm{t} \mathrm{ha}^{-1}$, in which $\mathrm{Mg}$ and P switched positions (Table 5). This result corroborates those obtained by Rodrigues et al. (2010), who observed the same sequence of accumulation in the parent plant, when evaluating different doses of $\mathrm{Zn}$ supplied through thinned sprouts for the banana cultivar Prata-Anã, under irrigated conditions in northern Minas Gerais.

Table 5. Order of nutrient accumulation in the different organs of the parent plant, follower and banana mat, in banana plots with history of different productivity classes

\begin{tabular}{|c|c|c|c|c|}
\hline \multirow{2}{*}{ Organs } & \multicolumn{4}{|c|}{ Productivity classes } \\
\hline & $<30$ & $30 \leq 37.5$ & $37.5 \leq 45$ & $>45 \mathrm{t} \mathrm{ha}^{-1}$ \\
\hline \multicolumn{5}{|c|}{ Parent plant } \\
\hline Rhizome & $\mathrm{K}>\mathrm{N}>\mathrm{Mg}>\mathrm{P}=\mathrm{Ca}>\mathrm{S}$ & $\mathrm{K}>\mathrm{N}>\mathrm{Ca}=\mathrm{Mg}>\mathrm{P}>\mathrm{S}$ & $\mathrm{K}>\mathrm{N}>\mathrm{Ca}>\mathrm{Mg}>\mathrm{P}>\mathrm{S}$ & $\mathrm{K}>\mathrm{N}>\mathrm{Ca}>\mathrm{P}=\mathrm{Mg}>\mathrm{S}$ \\
\hline Pseudostem & $\mathrm{K}>\mathrm{N}>\mathrm{Ca}>\mathrm{Mg}>\mathrm{P}>\mathrm{S}$ & $\mathrm{K}>\mathrm{N}>\mathrm{Ca}>\mathrm{Mg}>\mathrm{P}>\mathrm{S}$ & $\mathrm{K}>\mathrm{Ca}>\mathrm{N}>\mathrm{Mg}>\mathrm{P}>\mathrm{S}$ & $\mathrm{K}>\mathrm{N}>\mathrm{Ca}>\mathrm{Mg}>\mathrm{P}>\mathrm{S}$ \\
\hline Leaf & $\mathrm{K}>\mathrm{N}>\mathrm{Ca}>\mathrm{Mg}>\mathrm{P}=\mathrm{S}$ & $\mathrm{K}>\mathrm{N}>\mathrm{Ca}>\mathrm{Mg}>\mathrm{P}>\mathrm{S}$ & $\mathrm{K}>\mathrm{N}>\mathrm{Ca}>\mathrm{Mg}>\mathrm{P}>\mathrm{S}$ & $\mathrm{K}>\mathrm{N}>\mathrm{Ca}>\mathrm{P}=\mathrm{Mg}=\mathrm{S}$ \\
\hline Stalk & $\mathrm{K}>\mathrm{N}>\mathrm{P}=\mathrm{Ca}=\mathrm{S}>\mathrm{Mg}$ & $\mathrm{K}>\mathrm{N}>\mathrm{P}=\mathrm{Ca}=\mathrm{S}>\mathrm{Mg}$ & $\mathrm{K}>\mathrm{N}>\mathrm{P}=\mathrm{Ca}=\mathrm{S}>\mathrm{Mg}$ & $\mathrm{K}>\mathrm{N}>\mathrm{P}=\mathrm{Ca}>\mathrm{Mg}=\mathrm{S}$ \\
\hline Fruit & $\mathrm{K}>\mathrm{N}>\mathrm{P}>\mathrm{Mg}>\mathrm{S}>\mathrm{Ca}$ & $\mathrm{K}>\mathrm{N}>\mathrm{P}>\mathrm{Mg}>\mathrm{S}>\mathrm{Ca}$ & $\mathrm{K}>\mathrm{N}>\mathrm{P}>\mathrm{Mg}>\mathrm{Ca}>\mathrm{S}$ & $\mathrm{K}>\mathrm{N}>\mathrm{P}>\mathrm{Mg}>\mathrm{S}>\mathrm{Ca}$ \\
\hline \multicolumn{5}{|c|}{ Follower } \\
\hline Rhizome & $\mathrm{K}>\mathrm{N}>\mathrm{P}=\mathrm{Mg}>\mathrm{Ca}=\mathrm{S}$ & $\mathrm{K}>\mathrm{N}>\mathrm{P}=\mathrm{Mg}>\mathrm{Ca}>\mathrm{S}$ & $\mathrm{K}>\mathrm{N}>\mathrm{Ca}=\mathrm{Mg}>\mathrm{P}>\mathrm{S}$ & $\mathrm{K}>\mathrm{N}>\mathrm{P}>\mathrm{Mg}>\mathrm{Ca}>\mathrm{S}$ \\
\hline Pseudostem & $\mathrm{K}>\mathrm{N}>\mathrm{Ca}>\mathrm{Mg}>\mathrm{P}>\mathrm{S}$ & $\mathrm{K}>\mathrm{N}>\mathrm{Ca}>\mathrm{P}=\mathrm{Mg}>\mathrm{S}$ & $\mathrm{K}>\mathrm{N}>\mathrm{Ca}>\mathrm{Mg}>\mathrm{P}>\mathrm{S}$ & $\mathrm{K}>\mathrm{N}>\mathrm{Ca}>\mathrm{P}>\mathrm{Mg}>\mathrm{S}$ \\
\hline Leaf & $\mathrm{K}>\mathrm{N}>\mathrm{Ca}=\mathrm{Mg}>\mathrm{P}=\mathrm{S}$ & $\mathrm{K}>\mathrm{N}>\mathrm{Ca}>\mathrm{Mg}>\mathrm{P}=\mathrm{S}$ & $\mathrm{K}>\mathrm{N}>\mathrm{Ca}>\mathrm{Mg}>\mathrm{P}>\mathrm{S}$ & $\mathrm{K}>\mathrm{N}>\mathrm{Mg}=\mathrm{S}>\mathrm{P}=\mathrm{Ca}$ \\
\hline \multicolumn{5}{|c|}{ Overall average } \\
\hline Parent plant & $\mathrm{K}>\mathrm{N}>\mathrm{Ca}>\mathrm{Mg}>\mathrm{P}>\mathrm{S}$ & $\mathrm{K}>\mathrm{N}>\mathrm{Ca}>\mathrm{Mg}>\mathrm{P}>\mathrm{S}$ & $\mathrm{K}>\mathrm{N}>\mathrm{Ca}>\mathrm{Mg}>\mathrm{P}>\mathrm{S}$ & $\mathrm{K}>\mathrm{N}>\mathrm{Ca}>\mathrm{Mg}>\mathrm{P}>\mathrm{S}$ \\
\hline Follower plant & $\mathrm{K}>\mathrm{N}>\mathrm{Ca}>\mathrm{Mg}>\mathrm{P}>\mathrm{S}$ & $\mathrm{K}>\mathrm{N}>\mathrm{Ca}>\mathrm{Mg}>\mathrm{P}>\mathrm{S}$ & $\mathrm{K}>\mathrm{N}>\mathrm{Ca}>\mathrm{Mg}>\mathrm{P}>\mathrm{S}$ & $\mathrm{K}>\mathrm{N}>\mathrm{Ca}>\mathrm{Mg}>\mathrm{P}>\mathrm{S}$ \\
\hline Banana mat & $\mathrm{K}>\mathrm{N}>\mathrm{Ca}>\mathrm{Mg}>\mathrm{P}>\mathrm{S}$ & $\mathrm{K}>\mathrm{N}>\mathrm{Ca}>\mathrm{Mg}>\mathrm{P}>\mathrm{S}$ & $\mathrm{K}>\mathrm{N}>\mathrm{Ca}>\mathrm{Mg}>\mathrm{P}>\mathrm{S}$ & $\mathrm{K}>\mathrm{N}>\mathrm{Ca}>\mathrm{P}>\mathrm{Mg}>\mathrm{S}$ \\
\hline
\end{tabular}

In the different organs and productivity classes, $\mathrm{K}$ was the most accumulated macronutrient, followed by $\mathrm{N}$ (Table 5), corroborating the results obtained by Neves et al. (1991) for the cultivar Pacovan (AAB) and Hoffmann et al. (2010) for cultivars of various genotypes. The least accumulated macronutrient was $\mathrm{S}$, differing from the results obtained in other studies, in which $\mathrm{P}$ was the least accumulated macronutrient in banana plants (SOARES et al., 2008; HOFFMANN et al., 2010). In part, such lower accumulation of $\mathrm{S}$ in the plant is due to low and very low availability of the element in the soil (Table 1), different from $\mathrm{P}$, which had very good availability in all soils (ALVAREZ V. et al., 1999).
The nutrients $\mathrm{P}, \mathrm{Ca}$ and $\mathrm{Mg}$ varied regarding their accumulation in the different organs (Table 5). The stalk and fruit showed the same sequence of accumulation in the different classes of productivity, but differing from the other organs. As for $\mathrm{P}$, it was the third nutrient in export by these organs specifically, similar to the results obtained by Moreira and Fageria (2009a) for cultivar of the genotype AAB. 


\section{Nutritional efficiency}

The coefficient of biological utilization of the nutrient $\left(\mathrm{CBU} \mathrm{Nu}_{\mathrm{i}}\right)$ can be influenced by edaphoclimatic, biological and management factors, so it is difficult to establish relationships that effectively explain the values obtained in different situations (SILVA et al., 2009). These authors highlight the lack of information in the literature that makes it possible to relate the values of CBU_Nu $\mathrm{Nu}_{\mathrm{i}}$ with the factors that influence this variable, justifying the use of average values in the first versions of the nutritional balance systems (OLIVEIRA et al., 2005; DEUS et al., 2015).
In an attempt to mitigate this problem, the values of $\mathrm{CBU} \mathrm{Nu}_{\mathrm{i}}$ were correlated with the productivity in the different banana organs (Table 6). Oliveira et al. (2005) developed a model of fertilizer recommendation for banana based on nutritional balance, using the $\mathrm{CBU}_{-} \mathrm{Nu}_{\mathrm{i}}$ for exported biomass (stalk, fruit and female rachis) and returned biomass (rhizome, pseudostem, leaf, heart and male rachis). However, it can be observed that the CBU_Nu $\mathrm{Nu}_{\mathrm{i}}$ varies with productivity and also between plant organs (Table 6). Therefore, specific values for each organ are necessary to improvement fertilizer recommendations using $\mathrm{CBU} \mathrm{Nu}_{\mathrm{i}}$.

Table 6. Average values ${ }^{1}$ of the coefficient of biological utilization (CBU) of macronutrients, in the different organs of the banana tree, in plots with history of different productivity classes

\begin{tabular}{|c|c|c|c|c|c|c|c|}
\hline \multirow[t]{2}{*}{ Organs } & Productivity classes & $\mathrm{N}$ & $\mathrm{P}$ & $\mathrm{K}$ & $\mathrm{Ca}$ & $\mathrm{Mg}$ & $\mathrm{S}$ \\
\hline & \multirow[t]{2}{*}{$--\mathrm{t} \mathrm{ha}^{-1}--$} & \multicolumn{6}{|c|}{ - - - - - } \\
\hline & & \multicolumn{6}{|c|}{ Parent plant } \\
\hline \multirow{4}{*}{ Rhizome } & $<30$ & $190 \mathrm{a}$ & $970 \mathrm{a}$ & $46 \mathrm{a}$ & $1069 \mathrm{a}$ & 619 a & $1607 \mathrm{a}$ \\
\hline & $30 \leq 37.5$ & $153 \mathrm{a}$ & $903 \mathrm{a}$ & $31 \mathrm{a}$ & $572 b$ & $556 \mathrm{a}$ & $2042 \mathrm{a}$ \\
\hline & $37.5 \leq 45$ & $162 \mathrm{a}$ & $1083 \mathrm{a}$ & $43 \mathrm{a}$ & $482 \mathrm{~b}$ & $574 \mathrm{a}$ & $1833 \mathrm{a}$ \\
\hline & $>45$ & $224 \mathrm{a}$ & $784 \mathrm{a}$ & $39 \mathrm{a}$ & $611 b$ & $761 \mathrm{a}$ & $1265 \mathrm{a}$ \\
\hline \multirow{4}{*}{ Pseudostem } & $<30$ & $241 \mathrm{a}$ & $1090 \mathrm{a}$ & $46 \mathrm{a}$ & $111 \mathrm{a}$ & $447 \mathrm{~b}$ & $1958 \mathrm{a}$ \\
\hline & $30 \leq 37.5$ & $174 \mathrm{a}$ & $963 \mathrm{a}$ & $29 \mathrm{~b}$ & $119 \mathrm{a}$ & $395 \mathrm{~b}$ & $2125 \mathrm{a}$ \\
\hline & $37.5 \leq 45$ & $209 \mathrm{a}$ & $1165 \mathrm{a}$ & $42 \mathrm{a}$ & $87 \mathrm{a}$ & $398 \mathrm{~b}$ & $1917 \mathrm{a}$ \\
\hline & $>45$ & $244 \mathrm{a}$ & $1007 \mathrm{a}$ & $37 \mathrm{a}$ & $127 \mathrm{a}$ & $621 \mathrm{a}$ & $1694 \mathrm{a}$ \\
\hline \multirow{4}{*}{ Leaf } & $<30$ & $47 \mathrm{a}$ & $617 \mathrm{a}$ & $54 \mathrm{a}$ & $104 \mathrm{~b}$ & $368 \mathrm{~b}$ & $656 \mathrm{~b}$ \\
\hline & $30 \leq 37.5$ & $45 \mathrm{a}$ & $566 \mathrm{a}$ & $50 \mathrm{a}$ & $121 \mathrm{a}$ & $436 \mathrm{~b}$ & $830 \mathrm{a}$ \\
\hline & $37.5 \leq 45$ & $49 \mathrm{a}$ & $649 a$ & $49 \mathrm{a}$ & $102 \mathrm{~b}$ & $371 \mathrm{~b}$ & $785 \mathrm{a}$ \\
\hline & $>45$ & $59 \mathrm{a}$ & $618 \mathrm{a}$ & $48 \mathrm{a}$ & $129 \mathrm{a}$ & $530 \mathrm{a}$ & $597 \mathrm{~b}$ \\
\hline \multirow{4}{*}{ Stalk } & $<30$ & $71 \mathrm{a}$ & $476 \mathrm{~b}$ & $29 a$ & $384 \mathrm{a}$ & $1228 \mathrm{a}$ & $871 \mathrm{a}$ \\
\hline & $30 \leq 37.5$ & $47 \mathrm{~b}$ & $377 \mathrm{~b}$ & $24 \mathrm{a}$ & 397 a & $982 \mathrm{a}$ & $762 \mathrm{a}$ \\
\hline & $37.5 \leq 45$ & $70 \mathrm{a}$ & $637 \mathrm{a}$ & $24 \mathrm{a}$ & $323 \mathrm{~b}$ & $1319 \mathrm{a}$ & $748 \mathrm{a}$ \\
\hline & $>\overline{45}$ & $77 \mathrm{a}$ & $464 \mathrm{~b}$ & $27 \mathrm{a}$ & $331 \mathrm{~b}$ & $1112 \mathrm{a}$ & $871 \mathrm{a}$ \\
\hline \multirow{4}{*}{ Fruit } & $<30$ & $174 \mathrm{a}$ & $716 a$ & $61 \mathrm{a}$ & $5417 \mathrm{a}$ & $1146 \mathrm{a}$ & $1667 \mathrm{~b}$ \\
\hline & $30 \leq 37.5$ & $153 \mathrm{~b}$ & $671 \mathrm{a}$ & $61 \mathrm{a}$ & $5625 \mathrm{a}$ & $1028 \mathrm{~b}$ & $1917 \mathrm{a}$ \\
\hline & $37.5 \leq 45$ & $151 \mathrm{~b}$ & $760 \mathrm{a}$ & $55 \mathrm{~b}$ & $1586 \mathrm{~b}$ & $1111 \mathrm{a}$ & $1917 \mathrm{a}$ \\
\hline & $>45$ & $162 \mathrm{~b}$ & $679 a$ & $66 \mathrm{a}$ & $2667 \mathrm{~b}$ & $1181 \mathrm{a}$ & $1607 \mathrm{~b}$ \\
\hline \multicolumn{8}{|c|}{ Follower } \\
\hline \multirow{5}{*}{ Rhizome } & $<30$ & $203 \mathrm{a}$ & $920 \mathrm{a}$ & $50 \mathrm{a}$ & $1644 \mathrm{a}$ & $917 \mathrm{a}$ & $1833 \mathrm{a}$ \\
\hline & $30 \leq 37.5$ & $149 \mathrm{a}$ & $779 \mathrm{~b}$ & $47 \mathrm{a}$ & $944 \mathrm{~b}$ & $662 \mathrm{~b}$ & $2042 \mathrm{a}$ \\
\hline & $37.5 \leq 45$ & $165 \mathrm{a}$ & $928 \mathrm{a}$ & $41 \mathrm{a}$ & $647 \mathrm{~b}$ & $637 \mathrm{~b}$ & $2167 \mathrm{a}$ \\
\hline & $>45$ & $190 \mathrm{a}$ & $718 \mathrm{~b}$ & $46 \mathrm{a}$ & $1098 \mathrm{~b}$ & $911 \mathrm{a}$ & $1958 \mathrm{a}$ \\
\hline & $<30$ & $116 \mathrm{a}$ & $541 \mathrm{a}$ & $42 \mathrm{a}$ & $225 \mathrm{a}$ & $525 \mathrm{~b}$ & $1260 \mathrm{a}$ \\
\hline \multirow{3}{*}{ Pseudostem } & $30 \leq 37.5$ & $150 \mathrm{a}$ & $592 \mathrm{a}$ & $35 \mathrm{~b}$ & $196 \mathrm{a}$ & $543 \mathrm{~b}$ & $1756 a$ \\
\hline & $37.5 \leq 45$ & $111 \mathrm{a}$ & $525 \mathrm{a}$ & $31 \mathrm{~b}$ & $166 \mathrm{a}$ & $476 \mathrm{~b}$ & $1443 \mathrm{a}$ \\
\hline & $>45$ & $104 \mathrm{a}$ & $434 \mathrm{a}$ & $32 \mathrm{~b}$ & $255 \mathrm{a}$ & $647 a$ & $1061 \mathrm{a}$ \\
\hline \multirow{4}{*}{ Leaf } & $<30$ & $42 \mathrm{a}$ & $483 \mathrm{a}$ & $44 \mathrm{a}$ & $494 \mathrm{a}$ & 359 a & $508 \mathrm{~b}$ \\
\hline & $30 \leq 37.5$ & $39 \mathrm{a}$ & $492 \mathrm{a}$ & $44 \mathrm{a}$ & $354 \mathrm{a}$ & $404 \mathrm{a}$ & $657 \mathrm{a}$ \\
\hline & $37.5 \leq 45$ & $41 \mathrm{a}$ & $494 \mathrm{a}$ & $49 \mathrm{a}$ & $245 \mathrm{a}$ & $358 \mathrm{a}$ & $680 \mathrm{a}$ \\
\hline & $>45$ & $36 \mathrm{a}$ & $414 \mathrm{a}$ & $53 \mathrm{a}$ & $456 \mathrm{a}$ & $378 \mathrm{a}$ & $404 \mathrm{~b}$ \\
\hline
\end{tabular}

${ }^{1}$ Value referring to the average of four families for each class of productivity. Averages followed by the same letter in the column, for each organ, do not differ statistically from each other by the Scott-Knott test at $5 \%$ probability level. 
The macronutrients $\mathrm{Ca}$ and $\mathrm{Mg}$ were the ones that, for the highest number of organs, showed significant differences in CBU values between the productivity classes (Table 6), while N (stalk and fruit) and P (stalk and rhizome-follower) were different only for these organs. Thus, it can be stated that the CBUs of $\mathrm{N}$ and $\mathrm{P}$ are less sensitive to productivity variations, unlike those of $\mathrm{Ca}$ and $\mathrm{Mg}$. If $\mathrm{Mg}$ were a nutrient of low mobility in the phloem, part of this sensitivity could be attributed to the mobility; however, as it is mobile, certainly other factors are involved.

The CBU values for $\mathrm{K}$ in the fruits were higher than those obtained by Oliveira et al. (2005) for banana of the AAB group; however, these authors attributed the low $\mathrm{CBU}$ values for this nutrient to a possible luxury consumption of $\mathrm{K}$ by the plant, which may lead to recommendations of doses above the crop requirement.

In relation to the organs, the fruit had the highest number of macronutrients with significant difference between the productivity classes, except for P (Table 6). This result was expected because, for higher productivities a greater transport of nutrients is expected to occur to the fruits, changing the pattern of partitioning of elements in the plant and, consequently, influencing the values of CBU_Nu $\mathrm{Nu}_{\mathrm{i}}$.

\section{Conclusions}

Banana crop has a nutrient partitioning pattern as a function of different yields, and there is evidence that there is an "ideal compartmentalization" that promotes higher productivity. However, further studies are needed to support this statement.

The follower represents an important sink of nutrients in the banana mat during the harvest period, which should be considered at the time of the fertilizer recommendation.

The most exported nutrients per ton of bunch were $\mathrm{K}$ and $\mathrm{N}$.

The decreasing order of macronutrient accumulation (in the whole plant) was: $\mathrm{K}>\mathrm{N}>\mathrm{Ca}>\mathrm{Mg}>\mathrm{P}>\mathrm{S}$.

The CBUs of Nand Pwere less sensitive to productivity variations, while those of $\mathrm{Ca}$ and $\mathrm{Mg}$ were more sensitive

\section{Acknowledgements}

This study was financed in part by the Coordenação de Aperfeiçoamento de Pessoal de Nível Superior - Brasil (CAPES) - Finance Code 001; Conselho Nacional de Desenvolvimento Científico e Tecnológico - Brasil (CNPq) - Process No 141578/2014-9; and Sítio Barreiras Fruticultura Ltda for research support.

\section{References}

ALVAREZ V., V.H.; NOVAIS, R.F.; BARROS, N.F.; CANTARUTTI, R.B.; LOPES, A.S.I nterpretação dos resultados das análises de solos. In: RIBEIRO, A.C.; GUIMARAES, P.T.G.; ALVAREZ V., V.H.; (Ed.). Recomendações para o uso de corretivos e fertilizantes em Minas Gerais: $5^{a}$ aproximação.Viçosa: CFSEMG, 1999. p.25-32.

AULAR, J.; NATALE, W. Nutrição mineral e qualidade do fruto de algumas frutíferas tropicais: goiabeira, mangueira, bananeira e mamoeiro. Revista Brasileira de Fruticultura, Jaboticabal, v.35, n.4, p.1214-1231, 2013.

BARROS, N.F.; NOVAIS, R.F.; CARMO, D.N.; NEVES, J.C.L.Classificação nutricional de sítios florestais: descrição de uma metodologia. Revista Árvore, Viçosa, v.10, n.1, p.112-120, 1986.

BRITO, C.F.B.; FONSECA, V.A.; BEBÉ, F.V.; RAMOS, A.G.O.; SILVA, G.B. Production, decomposition and chemical characteristics of banana litterfall. Revista Caatinga, Mossoró, v.30, n.1, p.45-52, 2017.

CAVALCANTE, A.T.; SAMPAIO, E.V.S.B.; CAVALCANTE, U.M.T. Interdependência na absorção e redistribuição de fósforo entre planta mãe e filha de bananeira. Revista Brasileira de Fruticultura, Jaboticabal, v.27, n.2, p.255-259, 2005.

CRUZ, J.L.; COELHO, E.F.; PELACANI, C.R.; COELHO FILHO, M.A.; DIAS, A.T.; SANTOS, M.T. Crescimento e partição de matéria seca e de carbono no mamoeiro em resposta à nutrição nitrogenada. Bragantia, Campinas, v.63, n.3, p.351-361, 2004.

DEUS, J.A.L.; SOARES, I.; NEVES, J.C.L.; MEDEIROS, J.F.M.; MIRANDA, F.R. Fertilizer recommendation system for melon based on nutritional balance. Revista Brasileira de Ciência do Solo, Viçosa, MG, v.39, p.498511, 2015.

EMBRAPA. Sistema Brasileiro de classificação de solos. 3.ed. Brasília: Centro Nacional de Pesquisa de Solos. 2013. $353 \mathrm{p}$.

EPSTEIN, E.; BLOOM, A.J. Nutrição mineral de plantas: princípios e perspectivas. 2.ed. Londrina: Planta, 2006. 403 p. 
FRATONI, M.M.J.; MOREIRA, A.; MORAES, L.A.C.; ALMEIDA, L.H.C.; PEREIRA, J.C.R. Effect of nitrogen and potassium fertilization on banana plants cultivated in the Humid Tropical Amazon. Communications in Soil Science and Plant Analysis, New York, v.48, n.13, p.1511-1519, 2017.

HOFFMANN, R.B.; OLIVEIRA, F.H.T.; SOUZA, A.P.; GHEYI, H.R.; SOUZA JÚNIOR, R.F. Acúmulo de matéria seca e de macronutrientes em cultivares de bananeira irrigada. Revista Brasileira de Fruticultura, Jaboticabal, v.32, n.1, p.268-275, 2010.

MALAVOLTA, E. Manual de nutrição mineral de plantas. São Paulo: Agronômica Ceres, 2006. 631 p.

MALBURG, J.L.; LICHTEMBERG, L.A. Composição mineral de frutos de banana-variação estacional do teor de macroelementos na cv.Nanicão em Santa Catarina. In: CONGRESSO BRASILEIRO DE FRUTICULTURA, 8 ., 1986, Brasília. Anais [...] Brasília: EMBRAPA-DDT/ CNPq, 1986. p.65-69.

MARSCHNER, P. Marschner's mineral nutrition of higher plants. 3.ed. New York: Academic Press, 2012. $672 p$.

MELO, A.S.; FERNANDES, P.D.; SOBRAL, L.F.; BRITO, M.E.B.; DANTAS, J.D.M. Crescimento, produção de biomassa e eficiência fotossintética da bananeira sob fertirrigação com nitrogênio e potássio. Revista Ciência Agronômica, Fortaleza, v.41 n.3, p.417-426, 2010.

MOREIRA, A.; FAGERIA, N.K. Repartição e remobilização de nutrientes na bananeira. Revista Brasileira de Fruticultura, Jaboticabal, v.31, n.2, p.574581, 2009a.

MOREIRA, A.; FAGERIA, N.K. Yield, uptake, and retranslocation of nutrients in banana plants cultivated in upland soil of Central Amazonian. Journal of Plant Nutrition, New York, v.32, n.3, 443-457, 2009 b.

NEVES, R.L.L.; FERREYRA, F.F.H.; MACIEL, R.F.P.; FROTA, J.N.E. Extração de nutrientes em banana (Musa sp.) cv. Pacovan. Ciência Agronômica, Fortaleza, v.22, n.1/2, p.115-120, 1991.

OLIVEIRA, F.H.T.; NOVAIS, R.F.; ALVAREZ V., V.H.; CANTARUTTI, R.B. Desenvolvimento de um sistema para recomendação de adubação para a cultura da bananeira. Revista Brasileiro de Ciência do Solo, Viçosa, MG, v.29, n.1, p.131-143, 2005.
RATKE, R.F.; SANTOS, S.C.; PEREIRA, H.S.; SOUZA, E.D.; CARNEIRO, M.A.C. Desenvolvimento e produção de bananeiras Thap Maeo e Prata-Anã com diferentes níveis de adubação nitrogenada e potássica. Revista Brasileira de Fruticultura, Jaboticabal, v.34, n.1, p.277288, 2012.

RODRIGUES, M.G.V.; PACHECO, D.D.; NATALE, W.; SILVA, J.T.A.; DIAS, M.S.C. Distribuição da biomassa e minerais em "família" de bananeira 'prata-anã' adubada com zinco via broto desbastado. Revista Brasileira de Fruticultura, Jaboticabal, v.32, n.2, p.599-611, 2010.

SCOTT, A.J.; KNOTT, M. A cluster analysis method for grouping means in the analysis of variance. Biometrics, Washington, v.30, n.3, p.507-512, 1974.

SILVA, A.C.P.; BORGES, A.L.; COELHO, E.F. Acúmulo de nutrientes em Bananeira D 'Angola’ (Tipo Terra) sob doses de nitrogênio via água de irrigação. Revista Brasileira de Fruticultura, Jaboticabal, v.37, n.2, p.488496, 2015.

SILVA, A.P.; ALVAREZ V., V.H.; SOUZA, A.P.; NEVES, J.C.L.; NOVAIS, R.F.; DANTAS, J.P. Sistema de recomendação de fertilizantes e corretivos para a cultura do abacaxi - Fertcalc-abacaxi. Revista Brasileira de Ciência do Solo, Viçosa, MG, v.33, n.5, p.1269-1280, 2009.

SILVA, F.C. (Ed.). Manual de análises químicas de solos, plantas e fertilizantes. 2.ed. Brasília: Embrapa Informação Tecnológica; Rio de Janeiro: Embrapa Solos, 2009. 627p.

SOARES, F.A.L.; GHEYI, H.R.; FERNANDES, P.D.; OLIVEIRA, F.H.T.; SILVA, F.V.; ALVES, A.N; PEDROSA R.M.B. Partição de fotoassimilados em cultivares de bananeira irrigadas com águas de diferentes salinidades. Revista Brasileira de Engenharia Agrícola e Ambiental, Campina Grande, v.9, p.101-107, 2005. Suplemento.

SOARES, F.A.L.; GHEYI, H.R.; OLIVEIRA, F.H.T.; FERNANDES, P.D.; ALVES, A.N.; SILVA, F.V. Acúmulo, exportação e restituição de nutrientes pelas bananeiras "Prata Anã" e "Grand Naine". Ciência Rural, Santa Maria, v.38, n.7, p.2054-2058, 2008.

TEIXEIRA L.A.J.; RAIJ, B.V.; BETTIOL NETO, J.E. Estimativa das necessidades nutricionais de bananeiras do subgrupo Cavendish cultivadas no Estado de São Paulo. Revista Brasileira de Fruticultura, Jaboticabal, v.30, n.2, p.540-545, 2008. 